\title{
Does Radical trachelectomy (RT) during pregnancy have higher obstetrical and oncological risks than RT before pregnancy?
}

\author{
Shota Shinkai ( $\nabla$ syotuas@sapmed.ac.jp ) \\ Sapporo Medical University: Sapporo lka Daigaku https://orcid.org/0000-0002-9390-2753 \\ Shinichi Ishioka \\ Sapporo Medical University \\ Tasuku Mariya \\ Sapporo Medical University https://orcid.org/0000-0002-7110-980X \\ Yuya Fujibe \\ Sapporo Medical University \\ Miseon Kim \\ Sapporo Medical University \\ Masayuki Someya \\ Sapporo Medical University https://orcid.org/0000-0002-7911-2747 \\ Tsuyoshi Saito \\ Sapporo Medical University https://orcid.org/0000-0002-9148-1609
}

\section{Research Article}

Keywords: radical trachelectomy, uterine cervical cancer, pregnancy

Posted Date: March 11th, 2021

DOI: https://doi.org/10.21203/rs.3.rs-228984/v1

License: @ (i) This work is licensed under a Creative Commons Attribution 4.0 International License. Read Full License

Version of Record: A version of this preprint was published at Archives of Gynecology and Obstetrics on March 2nd, 2022. See the published version at https://doi.org/10.1007/s00404-021-06327-w. 


\section{Abstract \\ Purpose}

Radical trachelectomy (RT) with pelvic lymphadenectomy has become a new treatment option for young patients with uterine cervical cancer stages 1A2-1B1 who desire the preservation of their fertility. However, the application of RT for pregnant patients is still controversial. We comparatively studied both obstetrical and oncological outcomes of pregnant patients who underwent vaginal RT during pregnancy and those who underwent vaginal RT before pregnancy.

\section{Methods}

Both obstetrical and oncological results of eight patients who underwent vaginal RT with pelvic lymphadenectomy during pregnancy in our institute between 2010 and 2020 (Group A), and ten pregnant patients who underwent vaginal RT with pelvic lymphadenectomy before pregnancy during the same period (Group B) were reviewed based on their medical charts.

\section{Results}

There were no significant differences in blood loss, surgical time, or surgical completeness between Group A and Group B. Nor were there significant differences in obstetrical outcomes between the two groups. However, two of the eight patients in Group A had recurrence of the cancer. None of the patients in Group B has shown any signs of recurrence thus far.

\section{Conclusion}

Vaginal RT during pregnancy does not affect the obstetrical prognoses of patients with early invasive uterine cervical cancer, and it might be a tolerable treatment modality for them. However, oncologically, it should be performed carefully as there is a risk of recurrence.

\section{Introduction}

Cervical cancer is one of the most commonly diagnosed malignant diseases during pregnancy worldwide [1]. It accounts for about $36 \%$ of the malignant diseases diagnosed during pregnancy in Japan [2]. The standard treatment modality for patients with invasive uterine cervical cancer stage 1A2 or higher stages is total hysterectomy irrespective of pregnancy $[3,4]$. Recently radical trachelectomy (RT) with pelvic lymphadenectomy, originally proposed by Dargent et al. in 1988 [5], has become a new treatment option for young patients who desire the preservation of their fertility. As we reported before, we have already performed vaginal radical trachelectomy (RT) for 73 patients with early invasive uterine cervical cancer [6]. However, this operative modality is usually performed for nonpregnant patients.

RT for pregnant women is still experimental, and it is still controversial whether RT during pregnancy is a recommendable treatment modality for pregnant patients with early invasive uterine cervical cancer. The French Working Group on Gynecological Cancers in Pregnancy does not recommend RT during pregnancy [7]. On the other hand, the National Comprehensive Cancer Network (NCCN) guidelines for cervical cancer allow RT during pregnancy [8]

We have experienced 31 pregnancies in 24 patients after vaginal RT since 2003. Among them, RT during pregnancy was performed for eight patients. For pregnancy after RT there is still a high risk of preterm birth and abortion in spite of progress in the management for such patients. However, does RT during pregnancy have higher obstetrical and oncological risks than RT before pregnancy? 
In this report, we comparatively studied both obstetrical and oncological outcomes of pregnant patients who underwent vaginal RT during pregnancy and those who underwent vaginal RT before pregnancy.

\section{Patients And Methods}

Eight patients who underwent vaginal RT with pelvic lymphadenectomy during pregnancy in our institute between 2010 and 2020 (Group A), and ten pregnant patients who underwent vaginal RT with pelvic lymphadenectomy before pregnancy during the same period (Group B) were reviewed in this study. Patients who underwent transabdominal cerclage (TAC) and patients before 2010 were excluded from the study. The study protocol was approved by the review board and the ethics committee in our institute (approval number 05-26). Written informed consent was also obtained from each patient.

Clinical characteristics of the patients are summarized in Table 1. Various obstetrical parameters such as fetal growth, changes of uterine cervical length, infectious markers, and oncological parameters such as the results for uterine cervical cytology and tumor markers were obtained from medical records. 
Table 1

Clinical characteristics of Group A and Group B.

\begin{tabular}{|c|c|c|c|c|c|}
\hline Patient & age & parity $G(P)$ & clinical stage & Histology ${ }^{2}$ & diagnostic conization ${ }^{3}$ \\
\hline \multicolumn{6}{|l|}{ Group A } \\
\hline 1 & 32 & $1(0)$ & 1B1 & SCC & - \\
\hline 2 & 30 & $1(0)$ & 1B1 & SCC & - \\
\hline 3 & 34 & $2(0)$ & 1B1 & Adeno & - \\
\hline 4 & 32 & $2(0)$ & 1B1 & Adeno & - \\
\hline 5 & 41 & $1(0)$ & 1B1 & SCC & - \\
\hline 6 & 23 & $2(0)$ & $\| A$ & SCC & - \\
\hline 7 & 31 & $2(0)$ & 1B1 & SCC & + \\
\hline 8 & 29 & $2(0)$ & 1B1 & Adeno & - \\
\hline \multicolumn{6}{|l|}{ Group B } \\
\hline 9 & 34 & $1(0)$ & 1B1 & SCC & ૫ \\
\hline 10 & 29 & $2(0)$ & $1 \mathrm{~A} 2$ & Adeno & ૫ \\
\hline 11 & 36 & $1(0)$ & 1B1 & SCC & ] \\
\hline 12 & 37 & $2(1)$ & 1B1 & SCC & प \\
\hline 13 & 31 & $1(0)$ & 1B1 & SCC & - \\
\hline 14 & 29 & $2(0)$ & IB1 & Adeno & - \\
\hline 15 & 37 & $0(0)$ & 1B1 & SCC & - \\
\hline 16 & 31 & $0(1)$ & 1B1 & Adeno & - \\
\hline 17 & 31 & $0(0)$ & $1 \mathrm{~A} 2$ & SCC & प \\
\hline 18 & 36 & $0(1)$ & 1B1 & Adeno & - \\
\hline Difference $^{1}$ & n.s & n.s & n.s & n.s & n.s \\
\hline \multicolumn{6}{|c|}{ 1. "n.s" means statistically "not significant” between Group A and Group B. } \\
\hline \multicolumn{6}{|c|}{ Differences between Group A and Group B were estimated for age, the first } \\
\hline \multicolumn{6}{|c|}{ delivery or not, clinical stage 1B1 or others, SCC or adenocarcinoma, and the } \\
\hline \multicolumn{6}{|c|}{ diagnostic conization was performed or not, respectively } \\
\hline \multicolumn{6}{|c|}{ 2. "SCC" means squamous cell carcinoma. "Adeno" means adenocarcinoma. } \\
\hline 3. "+" mean & gno & conzatio & s done. "-" $\mathrm{n}$ & ns diagnos & conization was not don \\
\hline
\end{tabular}

The clinical indications for vaginal RT in our institute, including those for pregnant patients, are as follows: (1) age $\leqq 45$ years with a strong desire to preserve fertility, (2) International Federation of Gynecology and Obstetrics (FIGO) stage 1A1 with vascular space involvement, stage $1 \mathrm{~A} 2$ or stage $1 \mathrm{~B} 1$, (3) lesion size $\leqq 2 \mathrm{~cm}$, (4) squamous histology or 
adenocarcinoma (including adenosquamous carcinoma), and (5) no involvement of the upper endocervical canal as determined by colposcopy or magnetic resonance imaging (MRI), and no evidence of lymph node metastasis.

All of the patients except one had FIGO 2009 stages 1A2-1B1 uterine cervical cancer in this study. Vaginal RT was performed for one patient with stage IIA who strongly desired the preservation of fertility after repeated explanations to her and her family. Adjuvant chemotherapy using paclitaxel and carboplatin was used for her both during the pregnancy and after cesarean section. Assessment of pelvic lymph node metastasis was performed by laparotomy or laparoscopy at the time of vaginal RT. For pregnant patients, it was performed by magnetic resonance imaging (MRI) before the operation and lymph node sampling at the time of the operation.

Vaginal RT was performed based on a modification of the procedure of Dargent et al. Amputation height was preoperatively determined by transvaginal ultrasonography and a careful search of the lesion area by colposcopy for each patient. There were no differences of operative procedures between vaginal RT for pregnant patients and vaginal RT for non-pregnant patients.

Pelvic lymphadenectomy or lymph node sampling by laparotomy or laparoscopy was performed first, followed by vaginal RT. Briefly, a rim of vaginal mucosa was delineated circumferentially and excised so that the anterior and posterior mucosae could cover the cervix. The vesicovaginal space was defined laterally on each side. Then the descending branches of the uterine arteries and the cardinal ligaments were cut at the level of Type II hysterectomy. After this procedure, we usually amputated the uterine cervix $10 \mathrm{~mm}$ below the internal os of the uterus. A nylon suture was placed around the residual cervix to support cervical strength, and Strumdorf sutures were placed to cover the surface of the cervix. For pregnant patients, we confirmed the fetal status by ultrasonography soon after the operation, and carefully checked the amount of bleeding from the vaginal wound, and the existence of leakage of amniotic fluid. For pregnant patients, continuous prophylactic intravenous administration of tocolytic agents was performed for at least one week after RT.

Follow-up of the cancer was performed by periodical examination of cytology, tumor markers, CT scans, and/or MR imaging. Tumor marker examination and CT scans were not usually performed for pregnant patients.

For the management of pregnant patients after vaginal RT, there are as yet no international guidelines. Of course, there were no differences of the management methods between patients who underwent RT during pregnancy and those who underwent RT before pregnancy. Follow-up of pregnant patients after vaginal RT was performed according to a protocol described previously [6]. We recommend that patients enter hospitalization early in the second trimester of the pregnancy even if there are no signs of threatened abortion. Under hospitalization, patients undergo: (1) bed rest, (2) daily vaginal disinfection with $0.3 \%$ chlorhexidine, (3) prophylactic administration of an ulinastatin vaginal suppository, (4) routine examinations for bacterial vaginosis and maintenance of normal vaginal flora, (5) examination of the Nugent score, granulocyte elastase level and oncofetal fibronectin in vaginal secretion, serum CRP, general blood examination, and the administration of metronidazole in cases with a Nugent score $>5$, and/or that are cervical elastase or fibronectin positive, (6) routine examination of uterine cervical length using transvaginal ultrasonography, (7) long-term tocolysis using ritodrine hydrochloride, magnesium sulfate, and nifedipine for patients with abdominal pain/tension, or for those with the uterine cervical length shortened to $<2 \mathrm{~cm}$, and (8) weekly administration of a hydroxyprogesterone caproate depot.

Considering the maternal physical and psychological conditions from the long-term bed rest and tocolysis, and to avoid the sudden occurrence of preterm premature rupture of membranes (pPROM), cesarean section was usually scheduled at around 35 weeks of pregnancy except for patients who required emergent cesarean section.

Standard statistical tests, including Welch t-test, were used to analyze the clinicopathological data using Microsoft EXCEL 2016. A p-value of less than 0.05 was considered statistically significant. 


\section{Results}

Summaries of Group A and Group B are shown in Tables 1-5. There was no significant difference of age, stage, histology, and obstetrical factors between Group A and Group B. The average amount of bleeding at vaginal RT was $176 \mathrm{ml}$, and the average operative time was $97.5 \mathrm{~min}$ for Group A. The average amount of bleeding at vaginal RT was $84.4 \mathrm{ml}$, and the average operative time was $130 \mathrm{~min}$ for Group B (Table 2,3). There was no significant difference in surgical time or intraoperative bleeding between the two groups. No intraoperative problems occurred for patients and/or fetuses in either group. Genital bleeding after the operation was not marked for any patient of either group, and it usually stopped within 10 days after RT. The pathological specimens had negative surgical margins of over $10 \mathrm{~mm}$ for seven of the 8 patients in Group A and for all the 10 patients in Group B. One lymph node metastasis was detected in patient 6 with stage IIA cancer. She underwent periodic administration of paclitaxel and carboplatin until the scheduled cesarean section and also after the cesarean section as described in the Patients and Methods section. No other patients in Group A and Group B showed any distant metastatic lesions. Neither patients of Group A nor those of Group B had tumor invasion to the cardinal ligaments.

Table 2

Oncological outcomes of patients who underwent vaginal RT during pregnancy(Group A).

\begin{tabular}{|c|c|c|c|c|c|c|c|}
\hline & $\begin{array}{l}\text { operative } \\
\text { time(min.) }\end{array}$ & $\begin{array}{l}\text { bleeding } \\
(\mathrm{ml})\end{array}$ & $\begin{array}{l}\text { bleeding } \\
> \\
\text { 10days }\end{array}$ & $\begin{array}{l}\text { free } \\
\text { margin }\end{array}$ & $\begin{array}{l}\text { current } \\
\text { status }\end{array}$ & $\begin{array}{l}\text { recurrence } \\
\text { (Timing) }\end{array}$ & special remarks \\
\hline 1 & 93 & 150 & - & $>10 \mathrm{~mm}$ & NED 10years & - & \\
\hline 2 & 110 & 360 & - & $7-8 m m$ & NED 4years & $\begin{array}{l}\text { residual cervix } \\
\text { (24weeks of preg.) }\end{array}$ & \\
\hline 3 & 58 & 105 & - & inmm & NED 3years & - & \\
\hline 4 & 76 & 125 & - & > $10 \mathrm{~mm}$ & NED 3years & - & \\
\hline 5 & 121 & 264 & + & $>10 \mathrm{~mm}$ & NED 3years & - & \\
\hline 6 & 147 & 320 & - & $>10 \mathrm{~mm}$ & NED 2years & - & $\begin{array}{l}\text { Chemotherapy } \\
\text { during } \\
\text { pregnancy }\end{array}$ \\
\hline 7 & 43 & 20 & + & 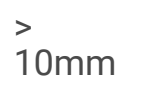 & $\begin{array}{l}\text { NED } \\
10 \text { months }\end{array}$ & - & \\
\hline 8 & 132 & 70 & - & $>10 \mathrm{~mm}$ & $\begin{array}{l}\text { under } \\
\text { treatment }\end{array}$ & $\begin{array}{l}\text { residual cervix } \\
\text { (2months after } \\
\text { delivery) }\end{array}$ & \\
\hline & Average $^{3}$ & average $^{3}$ & & & & & \\
\hline & $97.5^{*}$ & $176^{*}$ & & & & & \\
\hline \multicolumn{8}{|c|}{ 1."bleeding > 10days" means the existence of genital bleeding after vaginal RT } \\
\hline \multicolumn{8}{|c|}{ 2. "NED" means "clinically no evidence of disease". } \\
\hline
\end{tabular}


Table 3

Oncological outcomes of patients who underwent vaginal RT before pregnancy(Group B).

\begin{tabular}{|c|c|c|c|c|c|c|c|}
\hline & operative time(min.) & $\begin{array}{l}\text { bleeding } \\
(\mathrm{ml})\end{array}$ & $\begin{array}{l}\text { bleeding } \\
>\text { 10days }{ }^{1}\end{array}$ & $\begin{array}{l}\text { free } \\
\text { margin }\end{array}$ & $\begin{array}{l}\text { current } \\
\text { status }^{2}\end{array}$ & $\begin{array}{l}\text { recurrence } \\
\text { (Timing) }\end{array}$ & special remarks \\
\hline 9 & 188 & 100 & - & $>10 \mathrm{~mm}$ & NED 9years & - & \\
\hline 10 & 154 & 300 & - & $>10 \mathrm{~mm}$ & NED 6years & - & \\
\hline 11 & 114 & 20 & - & $>10 \mathrm{~mm}$ & NED 5years & - & \\
\hline 12 & 115 & 40 & - & $>10 \mathrm{~mm}$ & NED 5years & - & \\
\hline 13 & 114 & 20 & - & $>10 \mathrm{~mm}$ & NED 4years & - & \\
\hline 14 & 147 & 130 & - & $>10 \mathrm{~mm}$ & NED 3years & - & \\
\hline 15 & 74 & 84 & - & $>10 \mathrm{~mm}$ & NED 2years & - & twin pregnancy \\
\hline 16 & 55 & 60 & - & $>10 \mathrm{~mm}$ & NED 1years & - & \\
\hline 17 & 127 & 70 & - & $>10 \mathrm{~mm}$ & NED 2years & - & \\
\hline \multirow[t]{3}{*}{18} & 213 & 20 & - & $>10 \mathrm{~mm}$ & NED 8months & - & \\
\hline & Average $^{3}$ & average $^{3}$ & & & & & \\
\hline & $130 *$ & $84.4^{*}$ & & & & & \\
\hline \multicolumn{8}{|c|}{ 1."bleeding > 10days" means the existence of genital bleeding after vaginal RT } \\
\hline \multicolumn{8}{|c|}{ 2. "NED" means "clinically no evidence of disease". } \\
\hline
\end{tabular}


Table 4

Obstetrical outcomes of patients who underwent vaginal RT during pregnancy(Group A).

\begin{tabular}{|c|c|c|c|c|c|c|c|c|}
\hline Patient & $\begin{array}{l}\text { delivery } \\
\text { (weeks) }\end{array}$ & $\begin{array}{l}\text { baby } \\
\text { Weight(g) }\end{array}$ & $\begin{array}{l}\text { Apgar score } \\
\text { (1min./5min.) }\end{array}$ & $\begin{array}{l}\text { CAM } \\
\text { (placenta) }\end{array}$ & $\begin{array}{l}\text { highest } \\
\text { BV } \\
\text { score }^{1}\end{array}$ & pPROM & $\begin{array}{l}\text { shortening } \\
\text { rate } \\
\text { of } \mathrm{Cx}(\%)^{2}\end{array}$ & Tocolysis \\
\hline 1 & 34 & 2112 & $8 / 9$ & - & 7 & $\llbracket(34 w)$ & 26 & $\begin{array}{l}\text { Ritodrine } \\
\text { Hydrochloride }\end{array}$ \\
\hline 2 & 26 & 882 & $4 / 8$ & - & 2 & - & 46 & $\begin{array}{l}\text { Ritodrine } \\
\text { Hydrochloride }\end{array}$ \\
\hline 3 & 35 & 2156 & $7 / 9$ & - & 4 & - & 17 & $\begin{array}{l}\text { Ritodrine } \\
\text { Hydrochloride }\end{array}$ \\
\hline 4 & 35 & 2328 & $8 / 8$ & - & 5 & - & 49 & $\begin{array}{l}\text { Ritodrine } \\
\text { Hydrochloride }\end{array}$ \\
\hline 5 & 35 & 2400 & $8 / 9$ & - & 0 & - & 35 & $\begin{array}{l}\text { Ritodrine } \\
\text { Hydrochloride }\end{array}$ \\
\hline \multirow[t]{2}{*}{6} & 30 & 1188 & $7 / 8$ & - & 0 & - & 0 & $\begin{array}{l}\text { Isoxsuprine } \\
\text { hydrochloride }\end{array}$ \\
\hline & & & & & & & & $\begin{array}{l}\text { Ritodrine } \\
\text { Hydrochloride }\end{array}$ \\
\hline \multirow[t]{2}{*}{7} & 36 & 2248 & $8 / 9$ & - & 6 & - & 29 & Nifedipine \\
\hline & & & & & & & & $\begin{array}{l}\text { Magnesium } \\
\text { sulfate }\end{array}$ \\
\hline 8 & 35 & 2390 & $8 / 9$ & - & 8 & - & 8 & None \\
\hline Average ${ }^{3}$ & $33^{*}$ & $1963^{*}$ & $7 / 8^{*}$ & * & $4^{*}$ & * & $26.3^{*}$ & \\
\hline \multicolumn{9}{|c|}{ 1. "highest BV score" means the highest BV score during pregnancy. } \\
\hline \multicolumn{9}{|c|}{ 2."shortening rate of $\mathrm{Cx}$ " means (cervical length in the early pregnancy - minimum cervical length during pregnancy) } \\
\hline \multicolumn{9}{|c|}{ / cervical length in the early pregnancy } \\
\hline$"$ Th & as no & ical dif & e between $\mathrm{G}$ & $A$ and $G$ & B. & & & \\
\hline
\end{tabular}


Table 5

Obstetrical outcomes of patients who underwent vaginal RT before pregnancy(Group B).

\begin{tabular}{|c|c|c|c|c|c|c|c|c|}
\hline patient & $\begin{array}{l}\text { Delivery } \\
\text { (weeks) }\end{array}$ & $\begin{array}{l}\text { baby } \\
\text { Weight(g) }\end{array}$ & $\begin{array}{l}\text { Apgar score } \\
\text { (1min./5min.) }\end{array}$ & $\begin{array}{l}\text { CAM } \\
\text { (placenta) }\end{array}$ & $\begin{array}{l}\text { highest } \\
\text { BV } \\
\text { score }^{1}\end{array}$ & pPROM & $\begin{array}{l}\text { shortening } \\
\text { rate } \\
\text { of Cx(\%) }{ }^{2}\end{array}$ & tocolysis \\
\hline \multirow[t]{2}{*}{9} & \multirow[t]{2}{*}{33} & \multirow[t]{2}{*}{2294} & \multirow[t]{2}{*}{$6 / 6$} & \multirow[t]{2}{*}{+} & \multirow[t]{2}{*}{8} & \multirow[t]{2}{*}{-} & \multirow[t]{2}{*}{21} & $\begin{array}{l}\text { Ritodrine } \\
\text { hydrochloride }\end{array}$ \\
\hline & & & & & & & & $\begin{array}{l}\text { Magnesium } \\
\text { sulfate }\end{array}$ \\
\hline 10 & 34 & 2520 & $7 / 8$ & - & 6 & - & 13 & $\begin{array}{l}\text { Ritodrine } \\
\text { hydrochloride }\end{array}$ \\
\hline 11 & 35 & 2126 & $8 / 9$ & - & 3 & - & 42 & $\begin{array}{l}\text { Isoxsuprine } \\
\text { hydrochloride }\end{array}$ \\
\hline 12 & 35 & 2470 & $8 / 9$ & - & 1 & - & 27 & $\begin{array}{l}\text { Ritodrine } \\
\text { hydrochloride }\end{array}$ \\
\hline 13 & 34 & 3226 & $5 / 7$ & - & 1 & - & 22 & $\begin{array}{l}\text { Ritodrine } \\
\text { hydrochloride }\end{array}$ \\
\hline 14 & 35 & 2412 & $7 / 9$ & - & 2 & - & 44 & $\begin{array}{l}\text { Ritodrine } \\
\text { hydrochloride }\end{array}$ \\
\hline 15 & 30 & $1224 / 1499$ & $8 / 95 / 8$ & - & 3 & - & 50 & $\begin{array}{l}\text { Ritodrine } \\
\text { hydrochloride }\end{array}$ \\
\hline 16 & 36 & 2588 & $6 / 9$ & - & 0 & - & 44 & $\begin{array}{l}\text { Ritodrine } \\
\text { hydrochloride }\end{array}$ \\
\hline 17 & 31 & 1684 & $8 / 9$ & - & 0 & $\rrbracket(31 w)$ & 17 & None \\
\hline 18 & 37 & 2160 & $8 / 9$ & - & 10 & - & 0 & None \\
\hline Average $^{3}$ & $34^{*}$ & $2200^{*}$ & $7 / 8^{*}$ & * & $3.4^{*}$ & * & $28^{*}$ & \\
\hline \multicolumn{9}{|c|}{ 1. "highest BV score" means the highest BV score during pregnancy. } \\
\hline \multicolumn{9}{|c|}{ 2."shortening rate of $\mathrm{Cx}$ " means (cervical length in the early pregnancy — minimum cervical length during pregnancy) } \\
\hline \multicolumn{9}{|c|}{ / cervical length in the early pregnancy } \\
\hline
\end{tabular}

The obstetrical outcomes of Group A and Group B are summarized in Table 4 and Table 5. Fetuses in each group showed normal growth over the course of pregnancy. The cervical length measured by transvaginal ultrasonography was mostly stable during follow-up for both groups, and there were no differences of the changes in the cervical length. Markers for genital tract inflammation such as the granulocyte elastase level and the oncofetal fibronectin level in the vaginal secretions were also mostly within the normal ranges over the pregnancy for both groups. Control of the preterm labor was successful with the administration of tocolytic agents and bed rest. As mentioned in Patients and Methods, cesarean section was scheduled at around 35 weeks of pregnancy. However, for one patient who had recurrence during pregnancy (patient 2), cesarean section with abdominal radical hysterectomy $(\mathrm{RH})$ was performed at 26 weeks of pregnancy. In addition, for a patient with a twin pregnancy (patient 15), one with PPROM (patient 17), and one who underwent chemotherapy during pregnancy (patient 6), cesarean section was performed at around 30 weeks of pregnancy. 
As described in Table 2 and Table 3, two of the eight patients in Group A had recurrence of the cervical cancer. Patient 2 had recurrence in the residual cervix 8 weeks after RT, at 24 weeks of pregnancy. She underwent cesarean section with RH at 26 weeks of pregnancy. Her child has normal growth thus far, and she is alive without further recurrence. Patient 8 showed no abnormal cytology over the pregnancy. At the time of cesarean section, we could not find any abnormal masses around the uterus, and the washing cytology of the abdominal cavity was also negative. Her postpartum genital condition was good. However, in a postpartum checkup one month after the cesarean section, ascites retention at the Douglus pouch, and a slight elevation of tumor marker CA125 were detected. As MR-imaging of the uterus detected an abnormal mass deep in the residual cervix, and the cytology showed adenocarcinoma, we diagnosed recurrence of the cancer. We have started chemotherapy (paclitaxel with docetaxel) for her. Her child's growth is quite normal thus far. None of patients in Group B have shown any signs of recurrence.

\section{Discussion}

This study compared the obstetrical and oncological outcomes of patients who underwent vaginal RT during pregnancy with those of patients who underwent vaginal RT before pregnancy in a single institute.

Pregnancy after RT itself has an extremely high risk of preterm birth $[6,9,10]$. As is well known, the uterine cervix works not only as a mechanical support of the fetus but also as a barrier against intrauterine infection [11]. Large excision of the uterine cervix with RT might contribute to a decrease in such load-bearing capacity, along with an increased risk of infection by intravaginal bacteria, resulting in miscarriage or preterm birth. RT during pregnancy might have additional obstetrical and oncological risks. These possible risks include: (1) miscarriage and preterm birth due to the burden of the radical surgery during pregnancy, (2) the occurrence of pPROM due to chorioamnionitis (CAM) induced by cervical infection after RT during pregnancy, (3) massive bleeding of the pregnant uterus during the operation, and (4) increase of the recurrence of the cancer.

For (1), Ungar et al. reported a high rate of postoperative miscarriage when RT was performed in the first trimester of pregnancy [12]. A recent report by Douligeris et al. also showed a high abortion rate after abdominal RT during pregnancy [13]. Fetuses in the first trimester may not be able to tolerate the surgical stress of RT [14], although our patient number 6 , who underwent vaginal RT at ten weeks of pregnancy, did not show any signs of threatened abortion after the operation. On the other hand, we believe that the late second to the third trimester of pregnancy is too late to undergo RT. Aoki et al. reported that it was better to perform RT between 15 and 19 weeks of pregnancy [15]. We agree with their policy.

Manipulation of the enlarged uterus during the operation can be a stress to the intrauterine fetus and it sometimes causes uterine contractions, and an enlarged uterus also becomes an obstacle to performing pelvic lymphadenectomy. We also performed vaginal RTs during the second trimester of pregnancy before 20 weeks of pregnancy, except for one case in which cancer was detected in the third trimester of pregnancy. We experienced no fetal losses thought to be associated with the operation during pregnancy. Furthermore, RT is performed through either the abdominal or vaginal route. As we reported previously, vaginal RT for pregnant patients seems to have an advantage over abdominal RT in terms of the direct stress on the fetus in the uterus because vaginal RT does not need complicated intra-abdominal procedures [16]. Vaginal RT during pregnancy does not seem to affect the fetal condition as long as the operation is performed early in the second trimester of pregnancy before 20 weeks of pregnancy.

With regard to (2), both uterine contraction and uterine cervical infection can be a cause of pPROM. Manipulation of the uterus can be a cause of continuous uterine contraction after the operation. We usually performed continuous intravenous administration of tocolytic agents for several days after RT during pregnancy. These treatments were effective and no patients in Group A experienced abortion due to uterine contraction after RT. Is the surgical wound of the uterine cervix a focus of infection, leading to pPROM from CAM by intravaginal bacteria? As shown in Table 4, genital bleeding of the patients in Group A was almost stopped within 10 days after RT, regardless of its timing. We performed meticulous BV and preterm marker examinations, as well as blood tests, as we mentioned in Patients and Methods. Treatment of BV in normal 
pregnant women is still controversial. However, such routine examinations and treatment that starts at the timing of BV seem to be useful to prevent the occurrence of cervical and intrauterine infections in patients after RT [17]. The surgical wound of the uterine cervix seems not to be a cause of intrauterine infection that leads to pPROM as long as we conduct meticulous postoperative prophylaxis.

With regard to (3), uterine surgery during pregnancy is associated with enlarged blood vessels, and therefore we thought the amount of bleeding was likely to increase. However, in the present study, there was no significant difference in surgical time or intraoperative blood loss between the two groups. Yoshihara et al. also reported that there were no significant differences in the amount of bleeding during the operation among RT before pregnancy, RT during pregnancy, and RH [18]. We believe that RT during pregnancy does not increase the risk of massive intraoperative bleeding as long as it is performed during the appropriate period of pregnancy.

We found two recurrences (25\%) in the 8 patients who underwent RT during pregnancy. However, all the patients who underwent RT before pregnancy were free of recurrence during follow-up. Yoshihara et al. reported that there was no difference in oncological prognoses among abdominal RT before pregnancy, abdominal RT during pregnancy and abdominal radical hysterectomy $(\mathrm{RH})$. It is said that pregnancy has no effects on the progression of the cervical cancer [19] and, of course, it is generally accepted that there is no difference in oncological outcomes between vaginal RT and abdominal RT [20]. However, Capilna et al. reported that abdominal RT during pregnancy had better oncological results than vaginal RT during pregnancy [21]. They reported that two of ten patients (20\%) had recurrences after vaginal RT, though none of 11 patients did so after abdominal RT. Vaginal RT is less stressful for the fetus than abdominal RT because there is no laparotomy or strong traction of the uterus. However, vaginal RT is a more conservative operation than abdominal RT. Vaginal RT resects the parametrium at the level of type II hysterectomy, whereas abdominal RT can provide wider resection up to the level of type III resection [22]. Does such a conservative procedure of vaginal RT affect the recurrence of the cancer? None of the patients in this study had parametrial invasion, and it is widely accepted that the oncological prognoses of vaginal RT and abdominal RT are the same as long as the indication of the operation is appropreate. Considering that the site of recurrence was the residual cervix in both cases, we should have ensured a greater cancer-free margin for the operation for pregnant patients, though doing so might lead to an increase in preterm birth.

RT during pregnancy is still an experimental treatment because of the lack of large trials and randomized studies. In a PubMed search, as of September 2020, we found that only 28 cases of abdominal RT and 9 cases of vaginal RT had been reported $[18,23]$. However, we believe that RT for pregnant patients with early invasive uterine cervical cancer is a promising treatment modality. What is important is to conduct careful management for patients who undergo RT during pregnancy to detect recurrence as early as possible. It is said that management of uterine cervical cancer during pregnancy depends on 5 factors: the stage of the disease, nodal status, histological subtype of the tumor, term of pregnancy, and the desire to preserve fertility [24]. It might be useful to decide the management of pregnant patients with uterine cervical cancer based on these factors. The demand for the preservation of fertility among young patients with uterine cervical cancer is increasing. We believe future multicenter randomized trials to obtain a consensus on the indications, operative timing, and operative technique are important.

\section{Declarations}

\section{Acknowledgements}

The authors have no conflicts of interest to declare.

\section{Funding}

Not applicable 


\section{Competing interests}

The authors declare that they have no competing interests.

\section{Ethics approval and consent to participate}

This study adhered to the tenets of Declaration of Helsinki, and the study design was reviewed and approved by the Sapporo medical university's review board and the ethics committee (approval number:05-26). Permission to access and to use these data was also approved. A written informed consent to participate in the study and to publish the report was obtained from each patient.

\section{Consent for publication}

Not applicable

\section{Availability of data and materials}

Data will be available from corresponding author upon resendable request.

\section{Code availability}

Not applicable

\section{Author information}

\section{Affiliations}

Department of Obstetrics and Gynecology, Sapporo Medical University, Hokkaido, Japan

Shota Shinkai, Shinichi Ishioka, Tasuku Mariya, Yuya Fujibe, Miseon Kim, Masayuki Someya, Tsuyoshi Saito.

\section{Authors' contributions}

SS, SI,TM, and TS designed the research. All the authors attended the management of each patients as a treatment team. SS, YF, MK, and MS analyzed data. SI,TS supervised the research. SS, SI, and TS wrote the manuscript. All authors have read and approved the Manuscript.

\section{References}

1. Perrone AM, Bovicelli A, D’Andrill G et al (2019) Cervical cancer in pregnancy: Analysis of literature and innovative approaches. J Cell Physiol 234:14975-14990.

2. Kobayashi Y, Tabata T, Omori M et al (2019) A Japanese survey of malignant disease in pregnancy. Int J Clin Oncol 24:328-333.

3. Monk BJ, Montz FJ (1992) Invasive cervical cancer complicating intrauterine pregnancy: treatment with radical hysterectomy. Obstet Gynecol. 80:199-203, 1992.

4. Watanabe $Y$, Tsuritani $M$, Kataoka T et al (2009) Radical hysterectomy for invasive cervical cancer during pregnancy: a retrospective analysis of a single institute experience. Eur J Gynaecol Oncol 30:79-81.

5. Dargent D, Martin X, Sacchetoni A, Mathevet $P$ (2000) Laparoscopic vaginal radical trachelectomy: a treatment to preserve the fertility of cervical carcinoma patients. Cancer 88: 1877-1882. 
6. Shinkai S, Ishioka S, Mariya T et al (2020) Pregnancies after vaginal radical trachelectomy (RT) in patients with early invasive uterine cervical cancer: results from a single institute. BMC Pregnancy Childbirth 248: doi:10.1186/s12884020-02949-1

7. Morice P, Narducci F, Mathevet P (2009) French recommendations on the Management of Invasive Cervical Cancer During Pregnancy. Int. J. Gynecol Cancer 19 :1638-1641.

8. Koh WJ, Greer BE, Abu-Rusum NR (2016) NCCN Clinical Practice Guidelines in Oncology (NCCN Guidelines): Cervical Cancer MS 19-20.

9. Plante M (2013) Evolution in fertility-preserving options for early-stage cervical cancer:radical trachelectomy, simple trachelectomy, neoadjuvant chemotherapy. Int J Gynecol Cancer 23:982-989.

10. Okugawa K, Kobayashi H, Sonoda K et al (2017) Oncological and obstetric outcomes and complications during pregnancy after fertility-sparing abdominal trachelectomy for cervical cancer: a retrospective review. Int $\mathrm{J}$ Clin Oncol 22:340-346.

11. Takada S, Ishioka S, Endo T et al (2013) Difficulty in the management of pregnancy after vaginal radical trachelectomy. Int J Clin Oncol 18:1085-1090.

12. Ungar L, Smith JR, Palfalvi L et al (2006) Abdominal radical rachelectomy during pregnancy to preserve pregnancy and fertility. Obstet Gynecol 108:811-814.

13. Douligeris A, Prodromidou A, Psomiadou V et al (2020) Abdominal Radical Trachelectomy During Pregnancy: A Systematic Review of the Literature. J Gynecol Obstet Hum Reprod 49:101607 doi:10.1016/ j.jogoh. 2019. 07.003. Epub 2019 Jul 2

14. Karateke A, Cam C, Celik C et al (2010) Radical trachelectomy in late pregnancy:Is it an option? Eur J Obstet Gynecol and Reprod Biol 152:112-113.

15. Aoki Y, Inamine M, Ohishi S et al (2014) Radical abdominal trachelectomy for 1B1 cervical cancer at 17 weeks of gestation:A case report and literature review. Case Rep in Obstet Gynecol Article ID 926502

16. Umemoto M, Ishioka S, Mizugaki Y et al (2019) Obstetrical prognosis of patients who underwent vaginal radical trachelectomy (RT) during pregnancy. J Obstet Gynaecol Res 45:1167-1172.

17. Reiter S, Spadt SK (2019) Bacterial vaginosis:a promer for clinicians. Postgrad Med 131: 8-18.

18. Yoshihara K, Ishiguro T, Chihara M et al (2018) The safety and effectiveness of abdominal radical trachelectomy for early stage cervical cancer during pregnancy. Int J Gynecol cancer 28:782-787.

19. Botha MH, Rajaram S, Karunaratne K(2018) Cancer in pregnancy. Int J Gynecol Obstet 143:137-142.

20. Gizzo S, Ancina E, Saccardi C et al (2013) Radical trachelectomy: the first step of fertility preservation in young women with cervical cancer (Review). Oncol Rep 30:2545-2554.

21. Capilna ME, Szabo B, Besci J et al (2016) Radical trachelectomy performed during pregnancy. A review of the literature. Int J Gynecol Cancer 26:758-762.

22. Kim M, Ishioka S, Endo T et al(2016) Possibility of less radical treatment for patients with early invasive uterine cervical cancer. J Obstet Gynaecol Res 42:876-882.

23. Rodolakis A, Thomakos N, Sotiropoulou M et al (2018) Abdominal radical trahelectomy for early-stage cervical cancer during pregnancy: A provocative surgical approach. Overview of the literature and a single- institute experience. Int $\mathrm{J}$ Gynecol Cancer 28:1743-1750.

Page $13 / 14$ 
24. Peccatori FA, Azim HA Jr, Orecchia R, et al (2013) Cancer, pregnancy and fertility: ESMO clinical guidelines for diagnosis, treatment and follow-up. Ann Oncol 24(suppl 6):vi160-vi170. 